\title{
Bacterial vaginal infections in diabetic and non-diabetic women
}

\author{
K Lakshmi", Chitralekha Saikumar, V Illamani, Godfred A Menezes \\ From First International Science Symposium on HIV and Infectious Diseases (HIV SCIENCE 2012) \\ Chennai, India. 20-22 January 2012
}

\section{Background}

Vaginal infection is a common disease of women. After 40 years, there is a fall in estrogen production. An estrogen deficient vagina as well as the immunocompromised status due to diabetes can lead to growth of abnormal flora which may in turn lead to infections. Bacterial vaginal infections are often least understood and empirical antifungal therapy for any vaginal infection without high vaginal swab culture is still in practice. The aim of the study is to analyze the prevalence of bacterial vaginal infections in diabetic and non-diabetic women.

\section{Methods}

Fifty diabetic and fifty non-diabetic women of age 40-70 years were randomly selected from the patients attending SBMCH, Chennai. High vaginal swab specimens were collected from them and cultured aerobically and anaerobically. Biochemical tests were performed and the microorganisms identified. Antibiotic susceptibility pattern noted.

\section{Results}

The microorganisms isolated were bacteria, Candida spp, Trichomonas spp. The major pathogens were Escherichia coli (15\%), Klebsiella pneumoniae (2\%), Staphylococcus aureus (9\%) and Candida (16\%). Lactobacilli, Bacteroides fragilis and Peptostreptococcus spp. were the anaerobes isolated. E. coli, S.aureus, Candida spp. were 18\%, 12\%, $18 \%$ reported in diabetic women and $12 \%, 6 \%, 14 \%$ reported in non-diabetic women respectively.

\section{Conclusion}

The prevalence of pathogenic bacteria and Candida is more in diabetic women than the non-diabetic women.

\footnotetext{
* Correspondence: laksh45@gmail.com

* Correspondence: laksh45@gmail.com (SBMCH), Chennai, India
}

Pathogenic bacteria are found as frequently as the Candida. Hence, the practice of empirical antifungal therapy without taking high vaginal swab needs to be revised. The use of appropriate antibiotics along with antifungal drugs may be beneficial.

Published: 4 May 2012

doi:10.1186/1471-2334-12-S1-P63

Cite this article as: Lakshmi et al:: Bacterial vaginal infections in diabetic and non-diabetic women. BMC Infectious Diseases 2012 12(Suppl 1):P63.
Submit your next manuscript to BioMed Central and take full advantage of:

- Convenient online submission

- Thorough peer review

- No space constraints or color figure charges

- Immediate publication on acceptance

- Inclusion in PubMed, CAS, Scopus and Google Scholar

- Research which is freely available for redistribution

Submit your manuscript at www.biomedcentral.com/submit

\section{() Biomed Central}

